総 説
\|\|\|\|\|\|\|\|\|\|\|\|\|\|||||||||||||||||

安定同位体利用技術

\title{
微量溶存窒素化合物の同位体比測定について 一最新の測定技術とその応用—
}

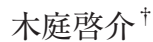 \\ 京都大学生態学研究センター \\ 520-2113 滋賀県大津市平野 2-509-3 \\ ${ }^{\dagger}$ keikoba@ecology.kyoto-u.ac.jp
}

\begin{abstract}
窒素安定同位体比は複雑な窒素循環の解析に長年使われてきたが, 必要試料量が大きいことが その利用のネックであった。近年，同位体比測定を $\mathrm{N}_{2}$ ガスではなく $\mathrm{N}_{2} \mathrm{O}$ ガスで行う測定法が開発 され, 特に環境中で微量にしか存在しない溶存態の微量窒素化合物についての窒素安定同位体比, さらに酸素安定同位体比を用いた研究が進んできている。本稿ではこの測定法を用いた最新の研 究について紹介する。
\end{abstract}

Key Words: Nitrogen isotope, Oxygen isotope, nitrous oxide

\section{1.はじめに：これまでの微量窒素化合物の同 位体比測定法の概略と問題点}

窒素が全ての生物に必須の元素であること, その一方で, 大気中に豊富に存在する窒素ガ ス $\left(\mathrm{N}_{2}\right)$ が容易には生物に利用可能でないこ となどから，一般に生態系内での窒素濃度は 低く，その回転速度が高いことが知られてい る。その結果として, 窒素の挙動を追跡するこ とは難しいことが多く, その重要性にもかかわ らず，たとえばある生態系の窒素収支を正確に 推定することはいまだに大変困難であるのが現 状である ${ }^{1)}$ 。一方で農業生産における窒素肥料 利用の増大, 人間活動に伴う窒素沈着の増大な どにより, 今や自然に生じている窒素固定速度 と同等の速度で大量の反応性窒素が生態系へと 供給されるようになってきている2)。この大量 の反応性窒素供給は，たとえば淡水資源の硝酸 污染，オゾン層破壊ガスであり同時に強力な温 室効果ガスでもある一酸化二窒素 $\left(\mathrm{N}_{2} \mathrm{O}\right)$ の放 出増加, 窒素飽和林の増加, 窒素とリンの農業 生態系に㧫けるアンバランス, など様々な問題
を引き起こしている。この状況は地球のこれま での歴史をさかのぼっても極めて異例の状況で あり, 様々な地球環境問題の中でも特に重要視 すべき項目として窒素循環は認識されるように なっている3)。

このような重要性を鑑み, 生態系における 窒素循環については古くから多くの研究がなさ れてきた。その中で生態系における窒素の循環 過程を研究するために，下記に述べるような 方法で ${ }^{15} \mathrm{~N}$ の利用が, そして窒素化合物の多く

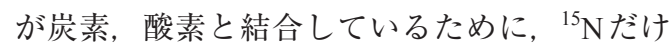
でなく ${ }^{13} \mathrm{C} や{ }^{18} \mathrm{O}$ の利用がなされてきた。 ${ }^{15} \mathrm{~N} に$ ついては， ${ }^{15} \mathrm{~N}$ 系へ添加する手法（いわゆる トレーサー法）が古くから積極的に用いられて おり， ${ }^{15} \mathrm{~N}$ の挙動を追跡するためにその対象化 合物中の ${ }^{15} \mathrm{~N}$ 濃度を発光分光法により測定して (た ${ }^{4)}$ 。その後, より高感度の安定同位体比質 量分析計（IRMS）の発展により, トレーサー レベルだけでなく自然存在比レベルの測定も 行われるようになっていった。その測定は，た とえば一例として有機物中の ${ }^{15} \mathrm{~N}$ 濃度測定を挙 げると,ケルダール法を用いて有機態窒素化合 
物をアンモニウム態窒素へ変換し，それをさら に $\mathrm{N}_{2}$ へと真空ラインを用いて変換しガラスア ンプルに封じ，その $\mathrm{N}_{2}$ をデュアルインレット 法でIRMSにより測定するというものである ${ }^{5)}$ 。 その後, 真空ラインを用いる燃焼法の詳細な検 討が行われ ${ }^{6}$, 有機態窒素化合物の自然存在比 レベルでの ${ }^{15} \mathrm{~N}$ と ${ }^{13} \mathrm{C}$ 測定が比較的容易になっ た。とはいえ，真空ラインを用いたガスの精製 はかなりの技術を必要とされるだけでなく，必 要試料量は約数 $\mathrm{mg}$ と大きかった。そのため, たとえば食物網研究で ${ }^{15} \mathrm{~N}$ と ${ }^{13} \mathrm{C}$ の自然存在比 （それぞれ $\delta^{15} \mathrm{~N}$ と $\delta^{13} \mathrm{C}$ ) が重要なパラメーター となることが明らかになった7) とはいえ，簡 便に利用できるような手法ではなかったのが当 時の状況であったと思われる。

90 年代に入り, IRMSのガス排気系の性能向 上に伴い，連続フロー型と呼ばれる測定が展開 されるようになった。たとえばガスクロマト グラフィーと連結し, 微量の化合物を分離し た後にマイクロ燃焼炉において燃焼させ，発 生した二酸化炭素ガス $\left(\mathrm{CO}_{2}\right)$ を直接IRMSへ と導入するといったいわゆるガスクロマトグ ラフィー連結燃燒型安定同位体比質量分析計 （GC-C-IRMS）が発展し ${ }^{8)}$, 現在も様々な改良 が行われている。これと平行して, 比較的大量 (数 $\mathrm{mg}$ ) の有機物などを酸化燃焼させ, 生成す る $\mathrm{N}_{2}$ と $\mathrm{CO}_{2}$ を高流速の（たとえば $100 \mathrm{~mL} / \mathrm{min}$ ) キャリヤガスにのせガスクロマトグラフィー で分離し, 分離した $\mathrm{N}_{2}$ と $\mathrm{CO}_{2}$ を直接安定同位 体比質量分析計へ導入する, いわゆる元素分析 計連結型安定同位体比質量分析計 (EA-IRMS)

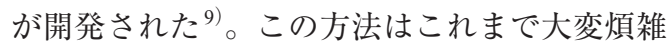
であった真空ラインによる試料由来のガス精製 を不要にし， 1 週間に数十検体が限界の精製ガ ラスアンプル作成, さらに続くそれらのデュア ルインレットによる同位体比測定（これも一 日20-30検体が限界)，というそれまでの測定 スピードを, 一週間で約 300 検体の測定へと劇 的に変化させた。一検体のEA-IRMSによる測 定において，元素分析計により炭素窒素濃度
情報が，そしてIRMSにより $\delta^{13} \mathrm{C} と \delta^{15} \mathrm{~N}$ 情報 がいっぺんに得られるということで，このEAIRMS は大変扱いやすく, 現在広く使われるよ うになっている。

先に述べたように，環境中の窒素はその回 転速度が高い。そのため駆動している窒素循環 の姿をより詳細に示すのは, 回転速度の特に高 い窒素画分である。そのような画分の代表であ る溶存している無機態窒素（DIN；たとえばア ンモニウムイオン, $\mathrm{NH}_{4}^{+}$や硝酸イオン, $\mathrm{NO}_{3}^{-}$) は, 環境中で数時間から数日の時間スケールで 生成と消費をくり返している。この重要な DIN について $\delta^{15} \mathrm{~N}$ 測定を行うことで，物質循環に ついての重要な情報を与えると期待できるた め, 古くから多くの研究がなされてきた。し かし，その回転速度の高さを反映して，DINの 実環境中での濃度は一般に大変低いため, その $\delta^{15} \mathrm{~N}$ 測定は困難であった ${ }^{10)}$ 。一方，環境中の DINや, 同様に回転速度の比較的高い溶存有機 態窒素化合物（DON）など溶存態の窒素の多

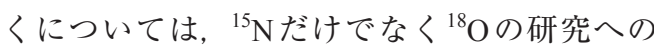
利用も可能性があるはずである（図1）。しか し，一般的なEA-IRMS では対象化合物を $\mathrm{N}_{2}$ の 形に変換して同位体比測定を行うため, 酸素同 位体比の情報を収集することは不可能であっ た。

この問題を克服するために, DINの中でも比 較的濃度が高く, その污染が社会問題となっ

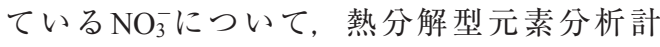
をIRMSに連結するシステム（TC/EA-IRMS） を用い, $\mathrm{NO}_{3}^{-}$を一酸化炭素ガス $(\mathrm{CO})$ へと 熱分解変換することにより ${ }^{18} \mathrm{O}$ の自然存在比 $\left(\delta^{18} \mathrm{O}\right)$ を測定する技術が開発された ${ }^{11)}$ 。現在 でもこの手法は比較的良く使われているが, $\mathrm{NO}_{3}^{-}$をTC/EA-IRMS にかけるための前処理（硝 酸銀沈殿作成）において有機物のコンタミネー ションを防ぐことが困難であること ${ }^{12)}, \mathrm{N}_{2}$ の $\mathrm{CO}$ 測定への妨害 ${ }^{13)}$, 熱分解中の酸素原子交 換 ${ }^{14)}$ といった問題があり，TC/EA-IRMSによ る $\mathrm{NO}_{3}^{-}$の $\delta^{18} \mathrm{O}$ 測定には注意が必要である ${ }^{15)} 。$ 


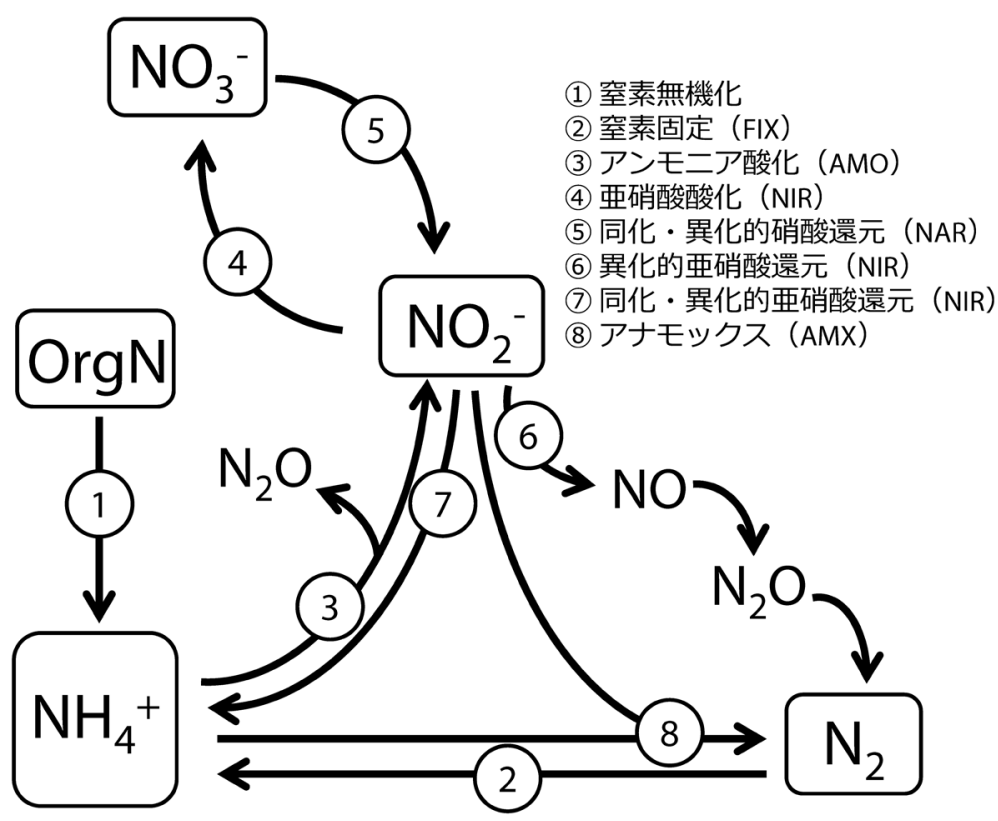

図 1 窒素循環の概略図。図2で取り上げる窒素循環プロセスについては英文字の略語をつけている。大変多くの プロセスが複雑に絡まっていること, そして化合物の多くが酸素原子も有していることに留意されたい

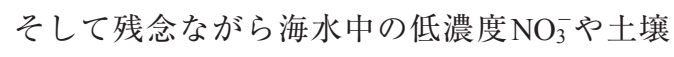
抽出液（しばしば高塩分をもつ水溶液で土壤を

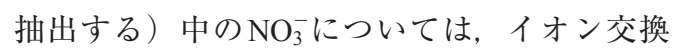
樹脂を用いた $\mathrm{NO}_{3}^{-}$濃縮と有機物除去, そして その後の硝酸銀沈殿生成, という TC/EA-IRMS 測定に必要な処理が困難なため測定が不可能で あった。

\section{2. $\mathrm{N}_{2} \mathrm{O}$ での同位体比測定技術}

最終測定化合物を $\mathrm{N}_{2}$ ではなく $\mathrm{N}_{2} \mathrm{O}$ にする方 法は以前より ${ }^{15} \mathrm{~N}$ トーサー法で開発されて いた ${ }^{16,17)}$ 。 $\mathrm{N}_{2} \mathrm{O}$ は大気中の濃度が約 $300 \mathrm{ppb}$ と 低く, 測定に招ける大気からのコンタミネー ションの影響が $\mathrm{N}_{2}$ と比べて遙かに小さい。ま た, ECD検出器を搭載したガスクロマトグラ フィーにより濃度定量が容易であるという利 点がある。しかし, これらの論文においては, $\mathrm{NO}_{3}^{-}$を $\mathrm{N}_{2} \mathrm{O}$ に変換する脱窒菌の取り扱いは微生 物生態の専門家が行っており, 物質循環研究を 中心に行っている研究者コミュニティーには, 微生物を利用するこの測定法は大変ハードルが
高いものであったと思われる。また, 実は同時 期にアジ化水素を用いて亜硝酸イオン $\left(\mathrm{NO}_{2}^{-}\right)$ を $\mathrm{N}_{2} \mathrm{O}$ に変換し, $\mathrm{NO}_{2}^{-}$の $\delta^{18} \mathrm{O}$ を測定した研究 が報告されていた ${ }^{18)}$ 。しかし, 当該論文でこ の測定を新測定手法として強調して報告した, ということではなかったため, 一般の同位体測 定コミュニティーが注目することはなかった。

同位体比測定において最終測定化合物を $\mathrm{N}_{2}$ ではなく $\mathrm{N}_{2} \mathrm{O}$ とすることは, 上記の $2 つ の$ 利点

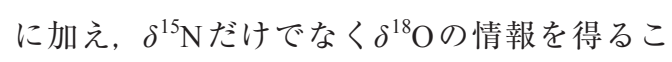
とができる可能性があること, 液体窒素温度 で $\mathrm{N}_{2} \mathrm{O}$ を濃縮することができ同位体比測定に 重要なキャリヤガス中での濃縮が可能であるこ と, という大きな利点がある。さらには 90 年 代に入り $\mathrm{N}_{2} \mathrm{O}$ をIRMS で測定した場合に得られ るイオンシグナルを用いた $\delta^{15} \mathrm{~N}$ と $\delta^{18} \mathrm{O}$ の計算 方法についての整理 ${ }^{19)}$, そしてGC-IRMSでの $\mathrm{N}_{2} \mathrm{O}$ の $\delta^{15} \mathrm{~N}$ そして $\delta^{18} \mathrm{O}$ 測定などが始まった ${ }^{20)}$ ことで, $\mathrm{N}_{2} \mathrm{O}$ を最終測定対象物として $\delta^{15} \mathrm{~N}$ 及 び $\delta^{18} \mathrm{O}$ を測定するための基礎的基盤が整備さ れたこととなった。しかしまだ問題はあり，た 
とえば $\mathrm{CO}_{2}$ の同位体比測定で問題となっている ように，同じような質量数をもつ $\mathrm{CO}_{2}$ と $\mathrm{N}_{2} \mathrm{O}$ の 分離の必要性, さらに $\delta^{18} \mathrm{O}$ 測定において $\mathrm{N}_{2} \mathrm{O}$ に化合物を変換する際の他化合物からの酸素の 取り込みを考慮する必要もあった。たとえば 微生物を用いて $\mathrm{NO}_{3}^{-}$を $\mathrm{N}_{2} \mathrm{O}$ に変換する際には, 水分子からの酸素原子が $\mathrm{N}_{2} \mathrm{O}$ に取り込まれる ことが知られており ${ }^{21)}$, その取り込み強度に はかなりの変動があることがわかってきてい る22)。

2000 年代に入り，プリンストン大のグルー プは，水分子からの酸素原子取り込み割合が小 さく, さらに最終脱窒産物が $\mathrm{N}_{2}$ ではなく $\mathrm{N}_{2} \mathrm{O}$ である脱窒菌を選定し, その培養プロトコル 並びに $\mathrm{N}_{2} \mathrm{O}$ 分離精製スキームを開発すること で，これまで測定が困難であった海洋中の低濃 度 $\mathrm{NO}_{3}^{-}$についての $\delta^{15} \mathrm{~N}^{23)}$ ならびに $\delta^{18} \mathrm{O}$ 測定 ${ }^{24)}$ を可能にした。この手法（しばしば脱窒菌法と 呼ばれる）により，濃縮が困難なイオン強度の 高い海水や土壤抽出液といった低 $\mathrm{NO}_{3}^{-}$濃度試 料, 溶存有機物により TC/EA-IRMS での測定や $\mathrm{NO}_{3}^{-}$の化学変換が妨害されやすい試料（湿地 水や植物抽出液, 堆積物間隙水など）について の $\delta^{15} \mathrm{~N} \cdot \delta^{18} \mathrm{O}$ 測定が可能となった。実際の行程 としては，まず，脱窒可能な状態に準備された 脱窒菌を含んだ夜体培地を閉鎖系ガラスバイア ルに入れ，そこに $\mathrm{NO}_{3}^{-}$を含んだ溶液試料を打 ち込むことで $\mathrm{N}_{2} \mathrm{O}$ を発生させる。一部は溶液 中に溶存している発生させた $\mathrm{N}_{2} \mathrm{O}$ ガスをへリ ウムガスで追い出し, 夾雑物である水蒸気及び $\mathrm{CO}_{2}$ を除去しながら数回にわたる寒剂を用いた 低温濃縮を行う（パージアンドトラップ）。さ らにガスクロマトグラフィーにより，低温濃 縮した $\mathrm{N}_{2} \mathrm{O}$ から $\mathrm{CO}_{2}$ を分離した上でIRMS に導 入する。この行程を実現するためにはパージ アンドトラップガスクロマトグラフィー連結 型IRMS（PT-GC-IRMS）が必要となり，良く 用いられているEA-IRMS と比較するとその導 入には高いハードルがある。しかしながら現在 までにその測定環境の構築, 脱窒菌の飼育, 校
正方法などについての情報が様々な論文におい て提供されており ${ }^{25-29)}$ ，後述する脱窒菌を用 いない化学的な $\mathrm{N}_{2} \mathrm{O}$ 生成についても情報がい くつも提供されている ${ }^{30-32)}$ 。それらの情報を 元に, 現在世界中の多くの研究機関でこのPTGC-IRMS 用いた $\mathrm{N}_{2} \mathrm{O}$ 法を用いた研究が様々 な分野で始まっている。また，この $\mathrm{N}_{2} \mathrm{O}$ を用い る測定技術（ $\mathrm{N}_{2} \mathrm{O}$ 法と以下呼ぶこととする）は $\mathrm{NO}_{3}^{-}$については脱窒菌ではなくアジ化水素を 使った化学反応を用いた測定法が開発 ${ }^{31)}$ され, さらにはアジ化水素を使った $\mathrm{NO}_{2}^{-}$の $\delta^{15} \mathrm{~N} \cdot \delta^{18} \mathrm{O}$ 測定 ${ }^{33)}, \mathrm{NO}_{2}^{-}$の酸素原子交換を利用した微量 海水の $\delta^{18} \mathrm{O}$ 測定 ${ }^{34)}$ ， $\mathrm{DON}$ ⿸ $\mathrm{NO}_{3}^{-}$に湿式酸化し た上での $\delta^{15} \mathrm{~N}$ 測定 ${ }^{30)}, \mathrm{NH}_{4}^{+}$の diffusion法によ る回収 ${ }^{35)}$ の後, $\mathrm{NO}_{3}^{-}$へと湿式酸化した上での $\delta^{15} \mathrm{~N}$ 測定 ${ }^{36,37)}, \mathrm{NH}_{4}^{+}$を $\mathrm{NO}_{2}^{-}$へと酸化した上で の $\delta^{15} \mathrm{~N}$ 測定 ${ }^{38)}$ ，さらにアミノ酸を $\mathrm{NO}_{2}^{-}$へ酸化 した上での $\delta^{15} \mathrm{~N}$ 測定 ${ }^{39)}$ ，と様々な手法が開発 されてきている。

\section{3. $\mathrm{N}_{2} \mathrm{O}$ 法による DIN 同位体比測定応用例}

$3 \cdot 1$ 窒素循環過程における同位体分別の算出 $\mathrm{N}_{2} \mathrm{O}$ 法によりこれまで測定が困難であった $\mathrm{DIN}$ ，特に $\mathrm{NO}_{3}^{-}$について比較的容易に $\delta^{15} \mathrm{~N}$ と $\delta^{18} \mathrm{O}$ が測定できるようになったため, 生物の DIN代謝における同位体分別についての情報 が近年多く集まってきている $\left(\right.$ 図 $\left.2^{40,41)}\right)$ 。た とえば硝化の一部分である好気的亜硝酸酸化 $\left(\mathrm{NO}_{2}^{-}\right.$が酸化され $\mathrm{NO}_{3}^{-}$になる微生物反応）にお

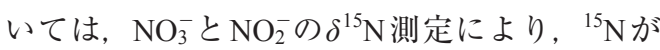
${ }^{14} \mathrm{~N}$ よも先に反応する逆同位体分別を示すこ とが明らかになった ${ }^{42)}$ 。この好気的亜硝酸酸 化における逆同位体分別は，酸素についても確 認され $\left.{ }^{43}, 44\right)$, さらにアナモックス反応に扔け る嫌気的亜硝酸酸化においても窒素について逆 同位体分別が報告されている ${ }^{45)}$ 。

また，植物プランクトンの $\mathrm{NO}_{3}^{-}$同化の際に 窒素同位体分別が生じることは古くから知ら れていたが46-48)，その同位体分別が $\mathrm{NO}_{3}^{-}$のプ ランクトン体内への取り込みの際に起きてい 


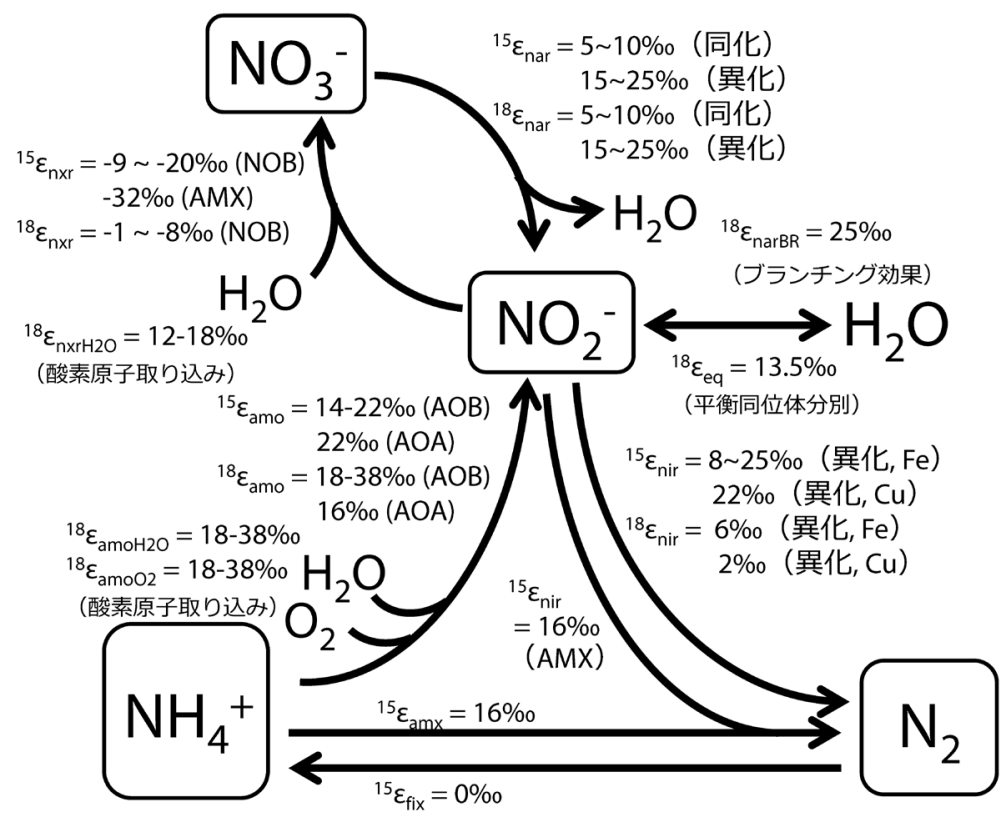

図2 窒素循環プロセスにおける同位体分別係数 ${ }^{40,41)}$ 。NOB は亜硝酸酸化バクテリア, AOA, AOB はそれぞれアン モニア酸化アーキア，バクテリア，AMXはアナモックス細菌を示している。また異なる酵素の場合は用い

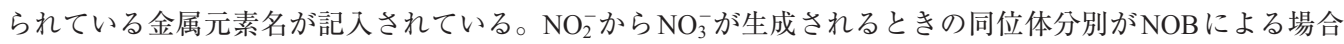
も，アナモックス細菌による場合も逆同位体分別を示すことに注意

るのか, それとも体内から同位体比が変化し た $\mathrm{NO}_{3}^{-}$が放出されることにより生じているの かについては不明であった。この問題は微量に 含まれる植物プランクトン体内の $\mathrm{NO}_{3}^{-}$と体外 の $\mathrm{NO}_{3}^{-}$の $\delta^{15} \mathrm{~N}$ そして $\delta^{18} \mathrm{O}$ 測定し，その違い を検討することで決着がついた。測定の結果,

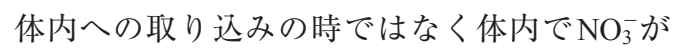
還元される際に同位体分別が生じ，その結果高 い ${ }^{15} \mathrm{~N}$ そて $\delta^{18} \mathrm{O}$ をつ体内 $\mathrm{NO}_{3}^{-}$が体外へと 放出されることが明らかとなった ${ }^{49)}$ 。これは Wada and Hattori $(1978)^{46)}$ で提案されていたス キームが正しかったことを示している。それた けでなく, $\mathrm{NO}_{3}^{-}$同化における $\delta^{15} \mathrm{~N}$ と $\delta^{18} \mathrm{O}$ の変 化度合いが $1: 1$ であることが示されたが，これ

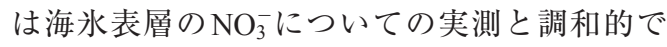
ある ${ }^{24)}$ 。さらには $\mathrm{NO}_{3}^{-}$の同化的還元だけでな く, 異化的還元（脱窒）においても，この $1: 1$ の変化の程度を示すこと ${ }^{50)}$ も明らかとなった。 近年では, この $1: 1$ についての詳細な議論, た とえば同化速度との関係や酵素による違いなど
が同化 ${ }^{51-54)}$ 及び脱窒 55-57) について展開されて いる（図3）。また, 硝化による $\mathrm{N}_{2} \mathrm{O}$ 発生の際 の同位体分別についても, これまで研究が進ん でいたアンモニア酸化細菌（AOB）による発 生 ${ }^{58)}$ とは異なる小さな窒素同位体分別がアン モニア酸化古細菌（AOA）による $\mathrm{N}_{2} \mathrm{O}$ 生成で 報告され ${ }^{59)}$, 海洋 $\mathrm{N}_{2} \mathrm{O}$ の同位体比のデータと 比較することで, 海洋での $\mathrm{N}_{2} \mathrm{O}$ 生成はアンモ ニア酸化古細菌による貢献が大きいことが示唆 された ${ }^{60)}$ 。

\section{$3 \cdot 2$ 実環境での微量窒素化合物同位体比測定} による研究例

$\mathrm{N}_{2} \mathrm{O}$ 法によってこれまで測定が不可能であっ

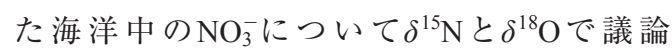
することが可能となった。これにより海水の $\delta^{18} \mathrm{O}$ が $0 \%$ であるのに対し, $\mathrm{NO}_{3}^{-}$の $\delta^{18} \mathrm{O}$ は深層 で $0 \%$ よりは高い值を取ること ${ }^{61)} や, \mathrm{NO}_{3}^{-}$の利 用における $1: 1$ の同位体比変動からのずれを使 うことにより, 硝化, 脱窒, 窒素固定のバラ 


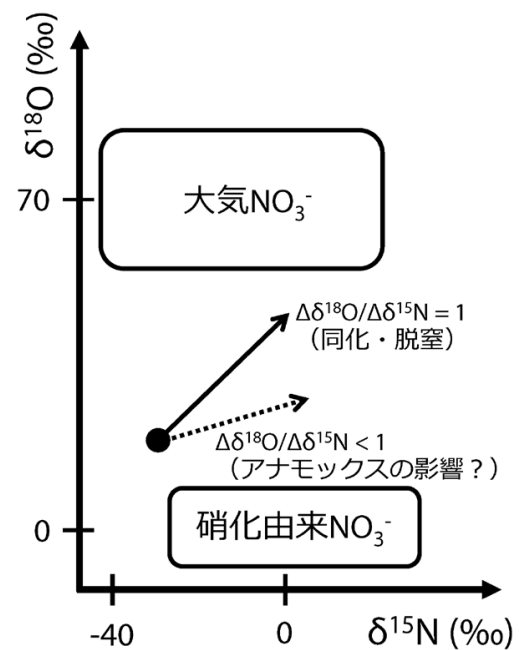

図3 $\mathrm{NO}_{3}^{-}$の $\mathrm{N}-\mathrm{O}$ 同位体マップの概略図 ${ }^{40,66)}$ 。横軸 縦軸の值はおおよその值を示している。 $\delta^{15} \mathrm{~N} て ゙$ は分離が困難であった大気と硝化由来の $\mathrm{NO}_{3}^{-}$ は $\delta^{18} \mathrm{O}$ を用いることで分離が可能となる。ま た, $\mathrm{NO}_{3}^{-}$が嫌気的に消費される場合は, $\delta^{18} \mathrm{O}$ と $\delta^{15} \mathrm{~N}$ の変化割合 $\left(\Delta \delta^{18} \mathrm{O} / \Delta \delta^{15} \mathrm{~N}\right)$ は脱窒 ${ }^{50)}$ と 同じく 1 をると報告されているが, 多くの淡 水生態系で報告されている值は 1 を下回ってい る。このことは逆同位体分別を伴うアナモック スによる硝酸イオンの生成が寄与している証拠 ではないかと示唆されている40)

ンスについての知見が得られること ${ }^{40,62)}$ など $\mathrm{NO}_{3}^{-}$の海洋での循環に関する様々な知見が得ら れるようになってきた。また, $\mathrm{NO}_{2}^{-}$の酸素原子 と水分子の酸素原子との同位体交換速度が時間 関数として表現できること ${ }^{63,64)}$ を利用し，海 洋中の $\mathrm{NO}_{2}^{-}$と $\mathrm{NO}_{3}^{-}$の $\delta^{15} \mathrm{~N}$ と $\delta^{18} \mathrm{O}$ 測定（実際に は $\mathrm{NO}_{2}^{-}$のアンモニア酸化の基質である $\mathrm{NH}_{4}^{+} ま$ たは懸濁態有機態窒素化合物の $\delta^{15} \mathrm{~N}$ 情報も必 要) により, 海洋での $\mathrm{NO}_{2}^{-}$滞留時間を求める 研究 ${ }^{64)}$ も始まっている。

陸上に目を向けてみると, 大気硝酸エアロ ゾル由来の大気 $\mathrm{NO}_{3}^{-}$と微生物により硝化で生

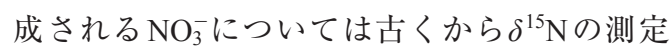
がなされてきたが, 残念ながら両者とも広い

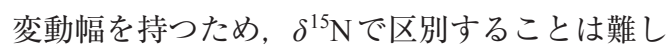
かった。しかし，その酸素原子については，大 気 $\mathrm{NO}_{3}^{-}$ではオゾン由来の酸素原子, 一方硝化
由来 $\mathrm{NO}_{3}^{-}$では水と酸素ガスの酸素原子という ように起源が両者で大きく異なる。そのため, $\delta^{18} \mathrm{O}$ については明確な違いがあり（図3), こ の違いを利用することにより，環境中の $\mathrm{NO}_{3}^{-}$

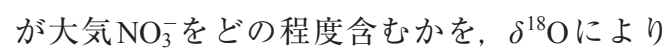
判定する研究が 90 年代に始まっていた ${ }^{65)}$ 。し かし，水銀を用いる当時の $\delta^{18} \mathrm{O}$ 測定法は極め て煩雑なもので, その大きな可能性にもかかわ らず研究はなかなか進展しなかった。この状 況が $\mathrm{N}_{2} \mathrm{O}$ 法により一変し, 大気 (降水) $\mathrm{NO}_{3}^{-}$ と土壤水, 河川水などに含まれる $\mathrm{NO}_{3}^{-}$の $\delta^{18} \mathrm{O}$ のデータが蓄積されるようになった ${ }^{66)}$ 。そし てこの知見を利用して, Durka et al. (1994) ${ }^{65)}$ にならい, 環境水中にどれだけ大気由来の $\mathrm{NO}_{3}^{-}$が含まれているかを推定する研究が盛ん に行われるようになった。たとえばOhte et al. $(2004)^{67)}$ では, 早春の渓流水中 $\mathrm{NO}_{3}^{-}$が雪

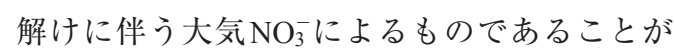
明らかにされている。Barnes et al. $(2008)^{68)}$ で は, アメリカ北西部の森林に扔いて溪流水中の $\mathrm{NO}_{3}^{-}$の 82-100\%が硝化由来であること, そし てマスバランス計算により, 大気 $\mathrm{NO}_{3}^{-}$の $3 \%$ 未 満という少ない量だけが渓流水へと流れ出てい ることが明らかにされた。同様に行われた和歌 山県のスギ人工林での結果では ${ }^{69)}$, 大気 $\mathrm{NO}_{3}^{-}$ の沈着量のうち5-13\%が渓流水へと流出して いること, 一方で伐採後数年の若い森林では 78\%が流出してしまっていることを報告してい る。

植物体内中の $\mathrm{NO}_{3}^{-}$がもつ同位体比は植物の $\mathrm{NO}_{3}^{-}$利用の観点だけでなく, 有機農法作物の 判別方法としても近年注目されつつある ${ }^{70-72)}$ 。 しかし植物プランクトンとは異なり, 植物の 体内中の $\mathrm{NO}_{3}^{-}$は大変低濃度であるため, その 同位体比測定は大変困難であり, その研究例は 極めて限られている ${ }^{72-75)}$ 。植物体内での $\mathrm{NO}_{3}^{-}$ の生成は窒素固定植物 ${ }^{76)}$ または貧酸素状態 ${ }^{77)}$ でなければ生じないと仮定すると, 通常の環 境で生育する植物の体内に $\mathrm{NO}_{3}^{-}$が存在すれば, それは $\mathrm{NO}_{3}^{-} を$ 吸収していたこと,さらにその 
$\delta^{15} \mathrm{~N}$ と $\delta^{18} \mathrm{O}$ が高ければ，硝酸還元における同 位体分別 ${ }^{78,79)}$ が発揮されたこと,つまり植物 が $\mathrm{NO}_{3}^{-}$を同化しているという証拠となる。陸 上の植物の窒素源を判定することは困難である ことから, 我々は, 植物の $\mathrm{NO}_{3}^{-}$同化の証拠と しての植物体内 $\mathrm{NO}_{3}^{-}$同位体比に着目し研究を 行ってきた。これまでの所, 多くの場合植物体 内に $\mathrm{NO}_{3}^{-}$が検出され, その $\delta^{15} \mathrm{~N}$ と $\delta^{18} \mathrm{O}$ は比較 的高い值をとることが分かってきた。つまり， 体内での $\mathrm{NO}_{3}^{-}$還元（同化）が示唆されるもの の ${ }^{80,81)}$, 実際には土壤の硝化由来 $\mathrm{NO}_{3}^{-}$のみで なく大気 $\mathrm{NO}_{3}^{-}$も葉面から吸収しており，それ らの $\mathrm{NO}_{3}^{-}$が体内で混ざり合っているという複 雑さが明らかにされた ${ }^{82)}$ 。

\section{4. 今後の $\mathrm{N}_{2} \mathrm{O}$ 法の展開}

環境中の微量DINを中心に研究例を紹介し てきたが，最終的に同位体比を測定する対象化 合物を $\mathrm{N}_{2} \mathrm{O}$ へと変換できれば, $\mathrm{N}_{2} \mathrm{O}$ 法の利用が 可能である。そこでこれまでに $\mathrm{DON}^{83,84)}$ ，七 ルソーターで集めた微量プランクトン ${ }^{85)}$, ポ ルフィリン ${ }^{86)}$, サンゴ骨格中の有機物 ${ }^{87-92)}$, 有孔虫中の有機物 ${ }^{93-95)}$, NOx ガス ${ }^{96-98)}$, と いった微量検体について $\mathrm{N}_{2} \mathrm{O}$ 法が展開されて いる。同時に, ${ }^{15} \mathrm{~N}$ トーサーとしても $\mathrm{N}_{2} \mathrm{O}$ 法 は有効であり ${ }^{99)}, \mathrm{N}_{2} \mathrm{O}$ 法を利用すればIRMS よ り安価かつ一般的に用いられている GC/MSに

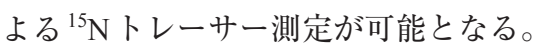

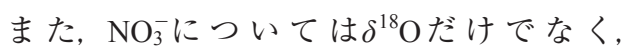
$\delta^{17} \mathrm{O}$ と $\delta^{18} \mathrm{O} の 一$ 般的な地球上での関係か らのずれ（酸素同位体比異常; $\Delta^{17} \mathrm{O}$ ）につ いても比較的微量で測定が可能となってき た ${ }^{29,100,101)}$ 。この $\Delta^{17} \mathrm{O}$ は同化や脱窒といった $\mathrm{NO}_{3}^{-}$の消費では変化せず, 異なる $\Delta^{17} \mathrm{O} を も$ つ $\mathrm{NO}_{3}^{-}$の混合でのみ変化するという特徵があ る ${ }^{102)}$ 。また, 大気 $\mathrm{NO}_{3}^{-}$が高い $\Delta^{17} \mathrm{O}$ をつのに 対して, 微生物由来の $\mathrm{NO}_{3}^{-}$が $0 \%$ という $\Delta^{17} \mathrm{O}$ をとるという特徴も有している ${ }^{102)}$ 。この2つ の特徵を合わせて利用することにより，環境中

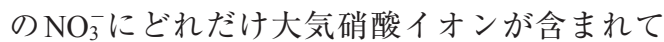

いるか， $\delta^{18} \mathrm{O}$ を用いるよりも精度良く推定する ことが可能となる ${ }^{103-108)}$ 。さらにある生態系に おいて大気 $\mathrm{NO}_{3}^{-}$のインプット速度とその $\Delta^{17} \mathrm{O}$, そして流出する $\mathrm{NO}_{3}^{-}$の $\Delta^{17} \mathrm{O}$ を求め, 定常状態 を仮定することで，生態系内でどれだけ $\mathrm{NO}_{3}^{-}$ が生成していたか，という総硝化速度を推定す ることが可能である ${ }^{105,109-111)}$ 。より進んだ利用 法として, $\mathrm{NO}_{3}^{-}$の生態系内での定常状態を仮定 し, $\mathrm{NO}_{3}^{-}$の土壤と渓流水での $\delta^{15} \mathrm{~N}$ 変化を脱窒 によるものと見なすことで生態系全体の脱窒速 度を見積もることができる可能性も示唆されて おり ${ }^{112)}, \mathrm{NO}_{3}^{-}$の三種同位体比測定によってさ らに詳細な窒素循環の解析が進むと期待されて いる。

\section{謝辞}

本研究は科学研究費補助金 (26252020) の援 助を受けたものである。

\section{文献}

1) Russell, A. E., et al., Rapidly growing tropical trees mobilize remarkable amounts of nitrogen, in ways that differ surprisingly among species, Proc. Natl. Acad. Sci. USA, 109, 10398-10402 (2012)

2) Peñuelas, J., et al., Human-induced nitrogen-phosphorus imbalances alter natural and managed ecosystems across the globe, Nat. Commun., 4, 2934 (2013)

3) Rockström, J., et al., A safe operating space for humanity, Nature, 461, 472-475 (2009)

4) Kumazawa, K., et al., Optical emission spectrographic studies on the distribution and accumulation of nanogram amounts of ${ }^{15} \mathrm{~N}$ in rice seedlings, Plant Cell Physiol., 10, 725-731 (1969)

5) Cheng, H. H., et al., Variations of nitrogen-15 abundance in soils, Science, 146, 1574-1575 (1964)

6) Minagawa, M., et al., Comparison of Kjeldahl and combustion methods for measurement of nitrogen isotope ratios in organic matter, Anal. Chem., 56, 1859-1861 (1984)

7) Minagawa, M., et al., Stepwise enrichment of ${ }^{15} \mathrm{~N}$ along food chains: Further evidence and the relation between $\delta^{15} \mathrm{~N}$ and animal age, Geochim. Cosmochim. Acta, 48, 1135-1140 (1984) 
8) Hayes, J. M., et al., Compound specific isotope analysis, a novel tool for reconstruction of ancient biochemical processes, Adv. Org. Geochem., 16, 1115-1128 (1990)

9) Preston, T., et al., Interfacing an automatic elemental analyser with an isotope ratio mass sepectrometer: The potential for fully automated total nitrogen and nitrogen-15 analysis, Analyst (Lond.), 108, 971-977 (1983)

10) 由水千景, 他, 安定同位体の可能性 2 分析の自 動化・高速化一硝酸イオン分析を例に一, 流 域環境評価と安定同位体（永田 俊, 宮島利 宏編), pp. 376-387 (2008)

11) Farquhar, G. D., et al., A rapid on line technique for determination of oxygen isotope composition of nitrogen containing organic matter and water, Rapid Commun. Mass Spectrom., 11, 1554-1560 (1997)

12) Chang, C. C. Y., et al., Nitrate stable isotopes: Tools for determining nitrate sources among different land uses in the Mississippi River Basin, Can. J. Fish. Aquat. Sci., 59, 1874-1885 (2002)

13) Sieper, H. P., et al., Essential methodological improvements in the oxygen isotope ratio analysis of $\mathrm{N}$-containing organic compounds, Rapid Commun. Mass Spectrom., 24, 2849-2858 (2010)

14) Révész, K., et al., Comparison of $\delta^{18} \mathrm{O}$ measurements in nitrate by different combustion techniques, Anal. Chem., 74, 5410-5413 (2002)

15) Xue, D., et al., Comparison of the silver nitrate and bacterial denitrification methods for the determination of nitrogen and oxygen isotope ratios of nitrate in surface water, Rapid Commun. Mass Spectrom., 24, 833-840 (2010)

16) Christensen, S., et al., Sub-parts-per-billion nitrate method: Use of an $\mathrm{N}_{2} \mathrm{O}$ producing denitrifier to convert $\mathrm{NO}_{3}^{-}$or ${ }^{15} \mathrm{NO}_{3}^{-}$to $\mathrm{N}_{2} \mathrm{O}$, Appl. Environ. $\mathrm{Mi}$ crobiol., 54, 1409-1413 (1988)

17) Højberg, O., et al., Determination of ${ }^{15} \mathrm{~N}$ abundance in nanogram pools of $\mathrm{NO}_{3}^{-}$and $\mathrm{NO}_{2}^{-}$by denitrification bioassay and mass spectrometry, Appl. Environ. Microbiol., 60, 2467-2472 (1994)

18) Shearer, G., et al., Nitrogen isotopic fractionation and ${ }^{18} \mathrm{O}$ exchange in relation to the mechanism of denitrification of nitrite by Pseudomonas stutzeri, J. Biol. Chem., 263, 13231-13245 (1988)

19) Tanaka, N., et al., High precision mass spectrometric analysis of isotopic abundance ratios in nitrous oxide by direct injection of $\mathrm{N}_{2} \mathrm{O}$, Int. J. Mass Spectrom. Ion Process., 142, 163-175 (1995)
20) Dore, J. E., et al., A large source of atmospheric nitrous oxide from subtropical North Pacific surface waters, Nature, 396, 63-66 (1998)

21) Ye, R. W., et al., $\mathrm{H}_{2}{ }^{18} \mathrm{O}$ isotope exchange studies on the mechanism of reduction of nitric oxide and nitrite to nitrous oxide by denitrifying bacteria, $J$. Biol. Chem., 266, 12848-12851 (1991)

22) Kool, D. M., et al., The ${ }^{18} \mathrm{O}$ signature of biogenic nitrous oxide is determined by $\mathrm{O}$ exchange with water, Rapid Commun. Mass Spectrom., 23, 104-108 (2009)

23) Sigman, D. M., et al., A bacterial method for the nitrogen isotopic analysis of nitrate in seawater and freshwater, Anal. Chem., 73, 4145-4153 (2001)

24) Casciotti, K. L., et al., Measurement of the oxygen isotopic composition of nitrate seawater and freshwater using the denitrifier method, Anal. Chem., 74, 4905-4912 (2002)

25) McIlvin, M. R., et al., Technical updates to the bacterial method for nitrate isotopic analyses, Anal. Chem., 83, 1850-1856 (2011)

26) 高津文人，他，硝酸イオンの窒素・酸素安定 同位体比測定のための自作による安価な自動 前処理ラインの開発, Radioisotopes, $60,231-$ 240(2011)

27) Weigand, M. A., et al., Updates to instrumentation and protocols for isotopic analysis of nitrate by the denitrifier method, Rapid Commun. Mass Spectrom., 30, 1365-1383 (2016)

28) Mcilvin, M. R., et al., Fully automated system for stable isotopic analyses of dissolved nitrous oxide at natural abundance levels, Limnol. Oceanogr. Methods, 8, 54-66 (2010)

29) Komatsu, D. D., et al., Determination of the ${ }^{15} \mathrm{~N} /{ }^{14} \mathrm{~N},{ }^{17} \mathrm{O} /{ }^{16} \mathrm{O}$, and ${ }^{18} \mathrm{O} /{ }^{16} \mathrm{O}$ ratios of nitrous oxide by using continuous-flow isotope-ratio mass spectrometry, Rapid Commun. Mass Spectrom., 22, 1587-1596 (2008)

30) Tsunogai, U., et al., Sensitive determinations of stable nitrogen isotopic composition of organic nitrogen through chemical conversion into $\mathrm{N}_{2} \mathrm{O}$, Rapid Commun. Mass Spectrom., 22, 345-354 (2008)

31) McIlvin, M. R., et al., Chemical conversion of nitrate and nitrite to nitrous oxide for nitrogen and oxygen isotopic analysis in freshwater and seawater, Anal. Chem., 77, 5589-5595 (2005)

32) Ryabenko, E., et al., Effect of chloride on the chemical conversion of nitrate to nitrous oxide for $\delta^{15} \mathrm{~N}$ analysis, Limnol. Oceanogr. Methods, 7, 545-552 
(2009)

33) Casciotti, K. L., et al., Oxygen isotopes in nitrite: Analysis, calibration, and equilibration, Anal. Chem., 79, 2427-2436 (2007)

34) McIlvin, M. R, et al., Method for the analysis of $\delta^{18} \mathrm{O}$ in water, Anal. Chem., 78, 2377-2381 (2006)

35) Holmes, R. M., et al., A simple and precise method for measuring ammonium in marine and freshwater ecosystems, Can. J. Fish. Aquat. Sci., 56, 18011808 (1999)

36) Koba, K., et al., Nitrogen isotopic analysis of dissolved inorganic and organic nitrogen in soil extracts, In: Earth, Life and Isotopes (eds. Ohkouchi, N., Tayasu, I. and Koba, K.), pp. 17-39 (2010)

37) Houlton, B. Z., et al., A climate-driven switch in plant nitrogen acquisition within tropical forest communities, Proc. Natl. Acad. Sci. USA, 104, 8902-8906 (2007)

38) Zhang, L., et al., Sensitive measurement of $\mathrm{NH}_{4}^{+}$ ${ }^{15} \mathrm{~N} /{ }^{14} \mathrm{~N}\left(\delta^{15} \mathrm{NH}_{4}^{+}\right)$at natural abundance levels in fresh and saltwaters, Anal. Chem., 79, 5297-5303 (2007)

39) Zhang, L., et al., Amino-group-specific natural abundance nitrogen isotope ratio analysis in amino acids, Rapid Commun. Mass Spectrom., 22, 559566 (2008)

40) Granger, J., et al., Isotopic overprinting of nitrification on denitrification as a ubiquitous and unifying feature of environmental nitrogen cycling, Proc. Natl. Acad. Sci. USA, 113, E6391-E6400 (2016)

41) Casciotti, K. L., Nitrite isotopes as tracers of marine $\mathrm{N}$ cycle processes, Phil. Trans. R. Soc. A, 374, 20150295 (2016)

42) Casciotti, K. L., Inverse kinetic isotope fractionation during bacterial nitrite oxidation, Geochim. Cosmochim. Acta, 73, 2061-2076 (2009)

43) Buchwald, C., et al., Oxygen isotopic fractionation and exchange during bacterial nitrite oxidation, Limnol. Oceanogr., 55, 1064-1074 (2010)

44) Buchwald, C., et al., Oxygen isotopic composition of nitrate and nitrite produced by nitrifying cocultures and natural marine assemblages, Limnol. Oceanogr., 57, 1361-1375 (2012)

45) Brunner, B., et al., Nitrogen isotope effects induced by anammox bacteria, Proc. Natl. Acad. Sci. USA, 110, 18994-18999 (2013)

46) Wada, E., et al., Nitrogen isotope effects in the assimilation of inorganic nitrogenous compounds, Geomicrobiol. J., 1, 85-101 (1978)
47) Wada, E., Nitrogen isotope fractionation and its significance in biogeochemical processes occurring in marine environments, In: Isotope Marine Chemistry (eds. Goldberg, E. D., Horibe, Y. and Saruhashi, K.), pp. 375-398 (1980)

48) Montoya, J. P., et al., Isotopic fractionation during nitrate uptake by phytoplankton growth in continuous culture, J. Plankton Res., 17, 439-464 (1995)

49) Granger, J., et al., Coupled nitrogen and oxygen isotope fractionation of nitrate during assimilation by cultures of marine phytoplankton, Limnol. Oceanogr., 49, 1763-1773 (2004)

50) Granger, J., et al., Nitrogen and oxygen isotope fractionation during dissimilatory nitrate reduction by denitrifying bacteria, Limnol. Oceanogr., 53, 2533-2545 (2008)

51) Granger, J., et al., $\mathrm{N}$ and $\mathrm{O}$ isotope effects during nitrate assimilation by unicellular prokaryotic and eukaryotic plankton cultures, Geochim. Cosmochim. Acta, 74, 1030-1040 (2010)

52) Karsh, K. L., et al., Eukaryotic assimilatory nitrate reductase fractionates $\mathrm{N}$ and $\mathrm{O}$ isotopes with a ratio near unity, Environ. Sci. Technol., 46, 5727-5735 (2012)

53) Karsh, K. L., et al., The contributions of nitrate uptake and efflux to isotope fractionation during algal nitrate assimilation, Geochim. Cosmochim. Acta, 132, 391-412 (2014)

54) Rohde, M. M., et al., Coupled nitrate $\mathrm{N}$ and $\mathrm{O}$ stable isotope fractionation by a natural marine plankton consortium, Front. Mater. Sci., 2, (2015) doi: $10.3389 /$ fmars. 2015.00028

55) Martin, T. S., et al., Nitrogen and oxygen isotopic fractionation during microbial nitrite reduction, Limnol. Oceanogr., 61, 1134-1143 (2016)

56) Treibergs, L. A., et al., Enzyme level $\mathrm{N}$ and $\mathrm{O}$ isotope effects of assimilatory and dissimilatory nitrate reduction, Limnol. Oceanogr., 62, 272-288 (2017)

57) Hosono, T., et al., Nitrogen, carbon, and sulfur isotopic change during heterotrophic (Pseudomonas aureofaciens) and autotrophic (Thiobacillus denitrificans) denitrification reactions, J. Contam. Hydrol., 183, 72-81 (2015)

58) Yoshida, $\mathrm{N} .,{ }^{15} \mathrm{~N}$-depleted $\mathrm{N}_{2} \mathrm{O}$ as a product of nitrification, Nature, 335, 528-529 (1988)

59) Santoro, A. E., et al., Isotopic signature of $\mathrm{N}_{2} \mathrm{O}$ produced by marine ammonia-oxidizing archaea, Science, 333, 1282-1285 (2011)

60) 布浦拓郎, 他, 海洋中の一酸化二窒素とア 
ンモニア酸化, 生物の科学遺伝, 68,504 508 (2014)

61) Sigman, D. M., et al., The dual isotopes of deep nitrate as a constraint on the cycle and budget of oceanic fixed nitrogen, Deep-Sea Res., 56, 1419-1439 (2009)

62) Sigman, D. M., et al., Nitrogen isotopes in the ocean, In: Encyclopedia of Ocean Sciences (eds. Steele, J. H., Turekian, K. K. and Thorpe, S. A.), Academic Press, London, pp. 40-54 (2009)

63) Nishizawa, M., et al., Nitrogen and oxygen isotope effects of ammonia oxidation by thermophilic Thaumarchaeota from a geothermal water stream, Appl. Environ. Microbiol., 82, 4492-4504 (2016)

64) Buchwald, C., et al., Isotopic ratios of nitrite as tracers of the sources and age of oceanic nitrite, Nat. Geosci., 6, 308-313 (2013)

65) Durka, W., et al., Effects of forest decline on uptake and leaching of deposited nitrate determined from ${ }^{15} \mathrm{~N}$ and ${ }^{18} \mathrm{O}$ measurements, Nature, 372, 765-767 (1994)

66) Kendall, C., et al., Tracing anthropogenic inputs of nitrogen to ecosystems, In: Stable Isotopes in Ecology and Environmental Sciences (eds. Michener, R. and Lajtha, K.), pp. 375-449 (2007)

67) Ohte, N., et al., Tracing sources of nitrate in snowmelt runoff using a high-resolution isotopic technique, Geophys. Res. Lett., 31, L21506 (2004)

68) Barnes, R. T., et al., Dual isotope analyses indicate efficient processing of atmospheric nitrate by forested watersheds in the northeastern U.S., Biogeochemistry, 90, 15-27 (2008)

69) Tobari, Y., et al., Contribution of atmospheric nitrate to stream-water nitrate in Japanese coniferous forests revealed by the oxygen isotope ratio of nitrate, Rapid Commun. Mass Spectrom., 24, 1281-1286 (2010)

70) Laursen, K. H., et al., Is it really organic?-Multiisotopic analysis as a tool to discriminate between organic and conventional plants, Food Chem., 141, 2812-2820 (2013)

71) Mihailova, A., et al., Stable isotope analysis of plant-derived nitrate- Novel method for discrimination between organically and conventionally grown vegetables, Food Chem., 154, 238-245 (2014)

72) 木庭啓介, 有機野菜は判定できるか：硝酸イ オン同位体比の利用可能性について, 現代化 学, 552, 38-40 (2017)

73) Yoneyama, T., et al., Variations in the natural abundance of ${ }^{15} \mathrm{~N}$ in nitrogenous fractions of komatsuna plants supplied with nitrate, Plant Cell Physiol., 30, 957-962 (1989)

74) Yoneyama, T., et al., Natural abundance of ${ }^{15} \mathrm{~N}$ in nitrate, ureides, and amino acids from plant tissues, Soil Sci. Plant Nutr., 45, 751-755 (1999)

75) Yoneyama, T., et al., Discrimination of nitrogen isotopes during absorption of ammonium and nitrate at different nitrogen concentrations by rice (Oryza sativa L.) plants, Plant Cell Environ., 24, 133-139 (2001)

76) Hipkin, C. R., et al., Nitrification by plants that also fix nitrogen, Nature, 430, 98-101 (2004)

77) Hill, R. D., Non-symbiotic haemoglobins-What's happening beyond nitric oxide scavenging? $A o B$ Plants, 2012, pls004 (2012)

78) Tcherkez, G., et al., Isotopic fractionation by plant nitrate reductase, twenty years later, Funct. Plant Biol., 33, 531-537 (2006)

79) Liu, X. Y., et al., Nitrogen and oxygen isotope effects of tissue nitrate associated with nitrate acquisition and utilisation in the moss Hypnum plumaeforme, Funct. Plant Biol., 39, 598-608 (2012)

80) Liu, X. Y., et al., Preliminary insights into $\delta^{15} \mathrm{~N}$ and $\delta^{18} \mathrm{O}$ of nitrate in natural mosses: A new application of the denitrifier method, Environ. Pollut., 162, 48-55 (2012)

81) Liu, X. Y., et al., Dual N and O isotopes of nitrate in natural plants: First insights into individual variability and organ-specific patterns, Biogeochemistry, 114, 399-411 (2013)

82) Liu, X. Y., et al., Nitrate dynamics in natural plants: Insights based on the concentration and natural isotope abundances of tissue nitrate, Front. Plant Sci., 5, 355 (2014)

83) Knapp, A. N., et al., N isotopic composition of dissolved organic nitrogen and nitrate at the Bermuda Atlantic Time-series Study site, Global Biogeochem. Cycles, 19, GB1018 (2005)

84) Knapp, A. N., et al., The distinct nitrogen isotopic compositions of low and high molecular weight marine DON, Mar. Chem., 136-137, 24-33 (2012)

85) Fawcett, S. E., et al., Assimilation of upwelled nitrate by small eukaryotes in the Sargasso Sea, Nat. Geosci., 4, 717-722 (2011)

86) Higgins, M. B., et al., A method for determining the nitrogen isotopic composition of porphyrins, Anal. Chem., 81, 184-192 (2009)

87) Yamazaki, A., et al., A 150 -year variation of the Kuroshio transport inferred from coral nitrogen 
isotope signature, Paleoceanography, 31, 838-846 (2016)

88) Yamazaki, A., et al., Nitrogen isotopes in intracrystal coralline aragonites, Chem. Geol., 351, 276-280 (2013)

89) Yamazaki, A., et al., Nitrogen isotopes of organic nitrogen in reef coral skeletons as a proxy of tropical nutrient dynamics, Geophys. Res. Lett., 38, L19605 (2011)

90) Erler, D. V., et al., Nitrogen isotopic composition of organic matter from a 168 year-old coral skeleton: Implications for coastal nutrient cycling in the Great Barrier Reef Lagoon, Earth Planet. Sci. Lett., 434, 161-170 (2016)

91) Wang, $X$. T., et al., Influence of open ocean nitrogen supply on the skeletal $\delta^{15} \mathrm{~N}$ of modern shallowwater scleractinian corals, Earth Planet. Sci. Lett., 441, 125-132 (2016)

92) Wang, X. T., et al., Isotopic composition of skeleton-bound organic nitrogen in reef-building symbiotic corals: A new method and proxy evaluation at Bermuda, Geochim. Cosmochim. Acta, 148, 179-190 (2015)

93) Costa, K. M., et al., No iron fertilization in the equatorial Pacific Ocean during the last ice age, $\mathrm{Na}$ ture, 529, 519-522 (2016)

94) Ren, H., et al., Foraminiferal isotope evidence of reduced nitrogen fixation in the ice age Atlantic Ocean, Science, 323, 244-248 (2009)

95) Ren, H. J., et al., Nitrogen isotopic composition of planktonic foraminifera from the modern ocean and recent sediments, Limnol. Oceanogr., 57, 10111024 (2012)

96) Walters, W. W., et al., Nitrogen stable isotope composition $\left(\delta^{15} \mathrm{~N}\right)$ of vehicle-emitted NOx, Environ. Sci. Technol., 49, 2278-2285 (2015)

97) Walters, W. W., et al., Nitrogen isotope composition of thermally produced NOx from various fossil-fuel combustion sources, Environ. Sci. Technol., 49, 11363-11371 (2015)

98) Fibiger, D. L., et al., First measurements of the nitrogen isotopic composition of NOx from biomass burning, Environ. Sci. Technol., 50, 11569-11574 (2016)

99) Isobe, K., et al., Analytical techniques for quantifying ${ }^{15} \mathrm{~N} /{ }^{14} \mathrm{~N}$ of nitrate, nitrite, total dissolved nitrogen and ammonium in environmental samples using a gas chromatograph equipped with a quadrupole mass spectrometer, Microbes Environ., 26, 46-53
(2011)

100) Kaiser, J., et al., Triple oxygen isotope analysis of nitrate using the denitrifier method and thermal decomposition of $\mathrm{N}_{2} \mathrm{O}$, Anal. Chem., 79, 599-607 (2007)

101) Hattori, S., et al., Automated system measuring triple oxygen and nitrogen isotope ratios in nitrate using the bacterial method and $\mathrm{N}_{2} \mathrm{O}$ decomposition by microwave discharge, Rapid Commun. Mass Spectrom., 30, 2635-2644 (2016)

102) Michalski, G., et al., First measurements and modeling of $\Delta^{17} \mathrm{O}$ in atmospheric nitrate, Geophys. Res. Lett., 30, 1870 (2003)

103) Michalski, G., et al., Tracing atmospheric nitrate deposition in a complex semiarid ecosystem using $\Delta{ }^{17} \mathrm{O}$, Environ. Sci. Technol., 38, 2175-2181 (2004)

104) Tsunogai, U., et al., Tracing the fate of atmospheric nitrate deposited onto a forest ecosystem using $\Delta^{17}$ O, Atmos. Chem. Phys., 10, 1809-1820 (2010)

105) Tsunogai, U., et al., Quantifying nitrate dynamics in an oligotrophic lake using $\Delta^{17} \mathrm{O}$, Biogeosciences, $\mathbf{8}$, 687-702 (2011)

106) Costa, A. W., et al., Analysis of atmospheric inputs of nitrate to a temperate forest ecosystem from $\Delta{ }^{17} \mathrm{O}$ isotope ratio measurements, Geophys. Res. Lett., 38, L15805 (2011)

107) Dejwakh, N. R., et al., Using ${ }^{17} \mathrm{O}$ to investigate nitrate sources and sinks in a semi-arid groundwater system, Environ. Sci. Technol., 46, 745-751 (2012)

108) Tsunogai, U., et al., Accurate and precise quantification of atmospheric nitrate in streams draining land of various uses by using triple oxygen isotopes as tracers, Biogeosciences, 13, 3441-3459 (2016)

109) Michalski, G., et al., The use of multi-isotope ratio measurements as a new and unique technique to resolve NOx transformation, transport and nitrate deposition in the Lake Tahoe Basin, The California Air Resources Board and the California Environmental Protection Agency (2006)

110) Riha, K. M., et al., High atmospheric nitrate inputs and nitrogen turnover in semi-arid urban catchments, Ecosystems (N.Y.), 17, 1309-1325 (2014)

111) Tsunogai, U., et al., Quantifying the effects of clearcutting and strip-cutting on nitrate dynamics in a forested watershed using triple oxygen isotopes as tracers, Biogeosciences, 11, 5411-5424 (2014)

112) Fang, Y., et al., Microbial denitrification dominates nitrate losses from forest ecosystems, Proc. Natl. Acad. Sci. USA, 112, 1470-1474 (2015) 
Abstract

\section{Applications of Stable Isotopes}

Measurements of the Natural Abundance of ${ }^{15} \mathrm{~N}$ and ${ }^{18} \mathrm{O}$ of Dissolved Nitrogen Compounds -The Latest Technical Improvements in the Analysis -

Keisuke $\mathrm{KoBA}^{\dagger}$ : Center for Ecological Research, Kyoto University, 2-509-3 Hirano, Otsu, Shiga Pref. 520-2113, Japan, ${ }^{\dagger}$ keikoba@ecology.kyoto-u.ac.jp

Recent developments of isotopic measurement with emphasis on $\mathrm{N}_{2} \mathrm{O}$ as the final analyte instead of $\mathrm{N}_{2}$, can provide great opportunities for scientists to measure $\delta^{15} \mathrm{~N}$ and $\delta^{18} \mathrm{O}$ of nitrogen compounds. The unique characteristics of $\mathrm{N}_{2} \mathrm{O}$ such as its low atmospheric concentration, can allow us to measure $\delta^{15} \mathrm{~N}$ and $\delta^{18} \mathrm{O}$ with only $20 \mathrm{nmol}-\mathrm{N}$ for nitrate. Moreover, this method is not only for nitrate and can be applicable as long as the target nitrogen compound, such as ammonium, nitrite, and dissolved organic nitrogen can be converted into $\mathrm{N}_{2} \mathrm{O}$. In this review, I introduce the applications of this method to investigate the complex $d y$ namics of nitrogen in the environments. 